Article

FELISBERTO, P.A.C. ${ }^{*}$ FELISBERTO, G. ${ }^{1}$

RAMOS, A.R. ${ }^{2}$

TIMOSSI, P.C. ${ }^{3}$

\section{MaIze CRop Phytotoxicity in Response to Sub-Doses OF SULFOMETURON-METHYL}

\author{
Fitotoxicidade na Cultura do Milho em Resposta a Subdoses de Sulfometuron- \\ Methyl
}

ABSTRACT - The use of ripeners has been a common practice in the sugarcane culture. The application of these products is often performed through aerial spraying, which increases the chances of drifting of the ripeners- molecules over the surrounding crops, such as maize. In order to study possible phytointoxication on maize caused by sulfometuron-methyl application, a field experiment was conducted to evaluate the effects of sulfometuron-methyl sub doses on maize when applied at the V4 and V8 development stages. The experiment was installed in a randomized block design with four replications. The treatments followed a 2 x 5 factor scheme, with the first factor corresponding to development stages of maize during which the ripener was applied (V4 and V8) and the second factor was related to sulfometuronmethyl sub doses $\left(0 ; 0.45 ; 0.90 ; 1.35\right.$ and $1.80 \mathrm{~g}$ a.i. $\left.\mathrm{ha}^{1}\right)$. The maize crop showed phytotoxicity with the use of $0.45 \mathrm{~g}$ a.i. ha ${ }^{-1}$ of sulfometuron-methyl; it was more severe when the application occurred at the development stage V8, leading the plant to death at the highest used dose. Furthermore, it was also possible to observe negative changes in the morphological and production components of maize plants. The SYN 7 G17 maize hybrid is highly susceptible to sulfometuron-methyl. The occurrence of sulfometuron-methyl deposits at higher doses or at different development stages of the crop may reflect more severe phytotoxic effects than the ones observed in this study.

Keywords: ripener, selectivity, Zea mays.

RESUMO - O uso de maturadores tem sido prática comum na cultura da cana-deaçúcar. A aplicação desses produtos ocorre muitas vezes por meio de pulverização aérea, o que aumenta as chances de ocorrer a deriva dessas moléculas em culturas circunvizinhas, como o milho. A fim de estudar possiveis fitointoxicações no milho ocasionadas pela aplicação de sulfometuron-methyl, foi realizado um experimento em campo com o objetivo de avaliar o efeito de sub doses desse maturador quando aplicado nos estádios de desenvolvimento V4 e V8 da cultura do milho. O experimento foi instalado no delineamento de blocos casualizados com quatro repetições. Os tratamentos seguiram o esquema fatorial $2 \times 5$, com o primeiro fator correspondente aos estádios de desenvolvimento do milho em que foi aplicado o maturador (V4 e V8), e o segundo, referente às sub doses de sulfometuron-methyl $\left(0 ; 0,45 ; 0,90 ; 1,35 ;\right.$ e $1,80 \mathrm{~g}$ i.a. $\left.\mathrm{ha}^{-1}\right)$. As plantas de milho apresentaram fitotoxicidade com o uso da subdose de $0,45 \mathrm{~g}$ i.a. $\mathrm{ha}^{-1}$ de sulfometuron-methyl, sendo esta mais severa quando a aplicação foi feita no estádio de desenvolvimento $V 8$, levando as plantas à morte nas maiores sub doses utilizadas. Ainda, observaramse também alterações negativas nos componentes morfológicos e de produção nas plantas de milho. O híbrido de milho SYN $7 G 17$ é altamente suscetivel ao

Planta Daninha 2017; v35:e017166504

1 Universidade Estadual Paulista (Unesp), Faculdade de Ciências Agrárias e Veterinárias, Jaboticabal-SP, Brasil; ${ }^{2}$ Universidade Estadual Paulista (Unesp), Faculdade de Ciências Agrárias, Botucatu-SP, Brasil; ${ }^{3}$ Universidade Federal de Goiás, Regional Jataí, Jataí-GO, Brasil. 
sulfometuron-methyl. A ocorrência de depósitos de sulfometuron-methyl em doses maiores ou ainda em diferentes estádios de desenvolvimento da cultura pode refletir em efeitos fitotóxicos mais graves do que os encontrados neste estudo.

Palavras-chave: maturador, seletividade, Zea mays.

\section{INTRODUCTION}

The use of ripeners is a common practice in the sugarcane culture and has the goal to accelerate and homogenize ripening, in order to guarantee a constant production flow during the year (Caputo et al., 2008; Leite and Crusciol, 2008; Dalley and Richard Jr., 2010); sulfometuronmethyl is one of the widely used ripeners (Correia and Vilella, 2015). The application of these products occurs often by aerial spraying, which increases the chances of drifting for the molecules adopted as ripener in other nearby cultures, such as maize (Felisberto et al., 2015).

Sulfometuron-methyl belongs to the chemical group of sulfonylurea, from the herbicide class of acetolactate synthase enzyme (ALS) inhibitors, also called acetohydroxy acid synthase (AHAS). ALS is the first enzyme of the branched chain amino acids synthesis route, valine, leucine and isoleucine (Zhou et al., 2007; Warwick et al., 2010). Herbicides derived from sulfonylurea, even when used in reduced doses or as ripeners, present high activity level and may have important implications, such as the alteration of metabolite processes balance and plant morphophysiology, which may interfere negatively on production (Meschede et al., 2010, 2011). They are active both via leaf and soil, and, after absorption, they are quickly transferred to active growth areas, meristems, apexes, where growth is inhibited in sensitive plants (Oliveira Júnior, 2011).

Visual phytotoxicity symptoms caused by sulfonylurea on plants that are sensitive to this chemical group are chlorotic leaf margins and laminas and reddish or purplish veins. In addition, leaves become wrinkled and with reduction or paralysis of the plant growth and development. Stronger symptoms include the appearance of a brownish color, death of terminal buds, with sprouting of lateral buds and inhibition of the root growth (Roman et al., 2007). Thus, plants may die due to the incapacity of producing the essential amino acids they need (Oliveira Junior, 2011).

In literature, there are works about plant phytointoxication caused by the application of sugarcane ripeners, such as ethephon and sulfometuron-methyl (Correia and Leite, 2012; Correia and Villela, 2015; Felisberto et al., 2015), as well as studies about the selectivity of herbicides derived from sulfonylurea (Burney and Jacobs, 2009; Pfleeger et al., 2010; Osiecka and Minogue, 2015). However, studies about the effect and the characterization of possible phytotoxicity symptoms, caused by sub-doses of sulfometuron-methyl on maize culture have not been conducted yet.

Similarly to other cultures (Correia and Leite, 2012; Correia and Vilella, 2015), maize culture is subjected to drifting risk or application errors of products such as ripeners (Felisberto et al., 2016). In this context, starting from the possible sensitivity of the maize culture to sulfometuronmethyl, the goal was to evaluate the effect of sub-doses of sulfometuron-methyl on maize culture when applied at the development stages V4 and V8.

\section{MATERIAL AND METHODS}

The experiment was conducted between January and June 2014, in an experimental area located in the city of Jataí, Goiás state. The geographical coordinates of the area are $17^{\circ} 55^{\prime} 37,3^{\prime \prime} \mathrm{S}$, $51^{\circ} 43^{\prime} 4,7^{\prime \prime} \mathrm{O}$ and altitude of $663 \mathrm{~m}$. The climate, according to Köppen (1931), is classified as Awa, savanna tropical, mesothermal, with two well-defined seasons, with rainy summer and dry winter, which helps two high yield annual crops under soybean-maize rotation system. According to the data registered by INMET (2014), the average maximum and minimum temperature of the region, during the conduction of the experiment, was $23.4^{\circ} \mathrm{C}$ and $21.8^{\circ} \mathrm{C}$, respectively, with total rainfall of approximately $796 \mathrm{~mm}$. 
The soil of the experimental area was classified as Distroferric Red Latosol with clayey texture; before the installation of the experiment, the soil analysis of the 0 to $0.2 \mathrm{~m}$ layer, for fertility purposes, presented the following characteristics: $\mathrm{pH}\left(\mathrm{CaCl}_{2}\right)=4.7$; soil organic matter $=40 \mathrm{~g} \mathrm{dm}^{-3}, \mathrm{P}\left(\right.$ Mehlich-1) $=4.82 \mathrm{mg} \mathrm{dm}^{-3}$; and $\mathrm{K}, \mathrm{Ca}, \mathrm{Mg}$ and $\mathrm{CTC}=0.12 ; 1.75 ; 0.31$ and $6.72 \mathrm{cmol}_{\mathrm{c}} \mathrm{dm}^{-3}$, respectively.

The experiment consisted in 10 treatments, established in a randomized block design with $2 \times 5$ factor scheme, with four replications. The first factor corresponded to the application at the development stages V4 and V8 of the maize culture, and the second one corresponded to sub doses of $0,0.45,0.90,1.35$ and $1.80 \mathrm{~g}$ a.i. ha $^{-1}$ of sulfometuron-methyl, which corresponded to 0,3 , 6,9 and $12 \%$ of the recommended dose of sulfometuron-methyl as sugarcane ripener $\left(15 \mathrm{~g}\right.$ a.i. ha $\left.{ }^{-1}\right)$.

Maize sowing was performed on $01 / 22 / 2014$ with a fertilization of $500 \mathrm{~kg} \mathrm{ha}^{-1} 08-20-18+$ $0.3 \% \mathrm{Zn}$. Each experimental unit was represented by 10 rows of the maize hybrid SYN 7G17, with a length of 9 meters. The distance between the rows was $0.45 \mathrm{~m}$, with an estimated population of 66,667 plants ha-1. Nine days after sowing (DAS), the application of the herbicide atrazine and tembotrione was performed for the management of weeds on total area. Top dressing was performed on day 24 DAS with $250 \mathrm{~kg} \mathrm{ha}^{-1}$ of urea.

On day 20 and 36 DAS, when maize plants had 4 (V4) and 8 (V8) fully expanded leaves, subdoses of sulfometuron-methyl were applied on six central rows of the plot, leaving two rows on each side with no application, to be used as side control samples of visual evaluations. To apply the treatments, $\mathrm{a} \mathrm{CO}_{2}$ pressurized backpack sprayer was used, equipped with a six DG 11002 flat spray nozzle bar, spaced $0.50 \mathrm{~m}$ apart, with a constant pressure of 2.8 bar and a spray volume equivalent to $200 \mathrm{~L}$ ha. A plastic sheet was placed beside the application, in order to avoid the contamination of the adjoining plots. During the application on day 20 DAS, the climate conditions at application time $(11: 08 \mathrm{AM})$ were $28.8{ }^{\circ} \mathrm{C}$ temperature, $71 \%$ relative air humidity and $8.4 \mathrm{~km} \mathrm{~h}^{-1}$ wind speed. During the application on day 36 DAS, the climate conditions at application time (09:26 AM) were $33.9{ }^{\circ} \mathrm{C}$ temperature, $50.1 \%$ relative air humidity and winds at $3.2 \mathrm{~km} \mathrm{~h}^{-1} \mathrm{speed}$

Visual evaluations of the phytotoxicity effects were performed 7, 14, 21, 28 and 42 days after the application (DAA), considering the lateral control sample as a reference, based on the plant intoxication rating scale of the EWRC (1964), which varies from 1 to 9, where the lowest value represents the absence of phytotoxicity and the highest one, the most extreme case, that is, plant death.

At the R1 development stage (flowering), stalk diameter (SD), first ear insertion height (EIH), plant height $(\mathrm{PH})$ and photosynthetically active leaf number count (PAL). In order to determine the SD, a digital millimeter caliper was used on the second internode from the soil surface. PH and EIH were determined with a centimeter topographic ruler and, to do so, the distance between the soil surface and the insertion point of the flag leaf and the first ear were considered, respectively. Leaves with more than $70 \%$ of green leaf area were considered in the PAL count. All evaluations were performed randomly on 10 plants from each experimental unit.

In each experimental unit, three four-meter long central maize rows (usable area) were harvested, totalizing $5.4 \mathrm{~m}^{2}$ of harvested area. Ten ears were separated randomly, in order to determine the number of rows of kernels (RK), number of kernels per row (KR) and ear length (EL). RK and KR were obtained from a simple count. EL was determined with the help of a measuring tape, starting from the ear base up to where it contains kernels. The kernel size (KS) was calculated starting from the subtraction of the value found between ear diameter and cob diameter and the division of the result by two.

Productivity was obtained from the mass of the kernels contained in the usable area of each experimental unit, through weighing (expressed in $\mathrm{kg} \mathrm{ha}^{-1}$ ), and adjusted to $13 \%$ water content. In order to determine the thousand kernel weight, two random counts were performed on eight replications with one hundred kernels (Brazil, 2009), which had their weight determined and adjusted to $13 \%$ water content, making it possible to estimate, through the average, the thousand kernel weight.

The obtained data were submitted to analysis of variance by $F$ test ( $p \leq 0.05)$, and quantitative data (sub-doses of sulfometuron-methyl), when significant, were submitted to regression analysis, through the statistical software GraphPad Prism@ Software 6.0. 


\section{RESULTS AND DISCUSSION}

\section{Visual symptom characterization}

It is possible to observe in Figure 1 that maize plants submitted to sub doses of sulfometuronmethyl at the development stages V4 and V8 presented altered development. The was an evolution in the phytotoxicity of the maize culture starting from sub-doses of $0.90 \mathrm{~g}$ a.i. ha ${ }^{-1}$ of sulfometuronmethyl, equivalent to $6 \%$ of the dose that was indicated as a sugarcane ripener, for the development stage V4, and starting from $0.45 \mathrm{~g}$ a.i. ha ${ }^{-1}$ of sulfometuron-methyl, for the development stage V8. Similar results were found by Miranda Filho and Novo (2006) when they studied the phytotoxicity of sulfonylurea on potato cultures. These authors reported that phytotoxicity increased according to the used dose and that, for metsulfuron-methyl and sulfometuron-methyl, plants had a remarkable delay of the vegetative cycle even at low doses.

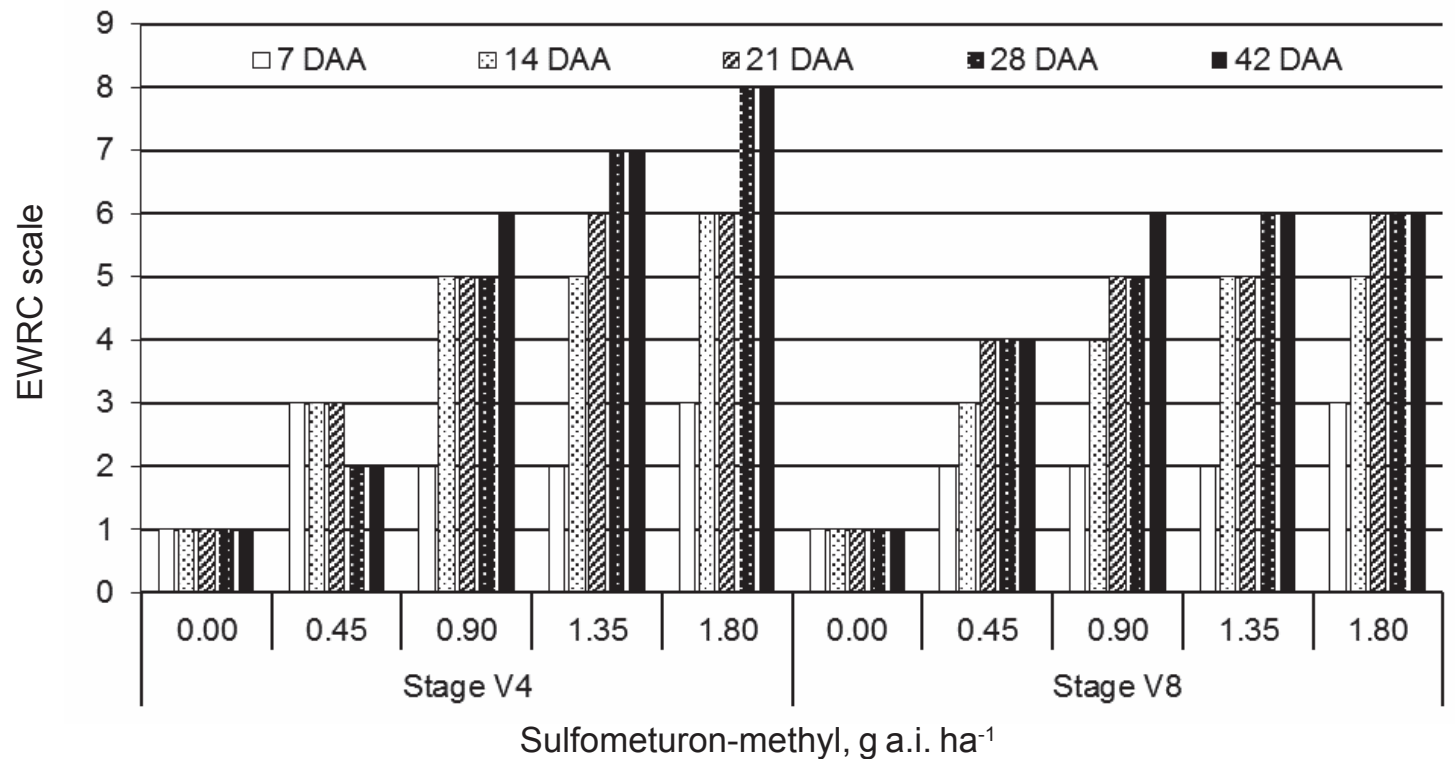

Figure 1 - Mode of the grades given in the evaluations of phytotoxicity symptoms for sulfometuron-methyl sub-doses on maize culture, according to the application at the development stages V4 and V8, following the EWRC grade scale (1964).

At the development stage V4, maize plants that received a $0.45 \mathrm{~g}$ a.i. ha ${ }^{-1}$ sub-dose of metsulfuron-methyl recovered starting from day 21 DAA. Thus, on day 7 DAA they obtained a grade 3 from the EWRC, that is, slight yellowing of the leaves and slight development delay that could be visible on many plants. Starting from day 28 DAA, damages became more perceptible (grade 2), remaining until day $42 \mathrm{DAA}$, that is, small alterations were visible on some plants. In a study conducted by Correia and Villela (2015), it was possible to observe that eucalyptus seedlings exposed to the application of sulfometuron-methyl also recovered from the damages and stopped presenting visual phytotoxicity symptoms of abnormal growth on day 60 DAA.

At the development stage V8, unlike what was observed on plants that received $0.45 \mathrm{~g}$ a.i. ha ${ }^{-1}$ of sulfometuron-methyl at the development stage V4, plants did not show recovery during the evaluations and presented EWRC grade of 2, 3, 4, 4 and 4 on day 7, 14, 21, 28 and 42 DAA, respectively. Thus, on day 7 DAA plants presented a slight yellowing on the apex of the new leaves, and on day 14 DAA, this yellowing became more marked as the leaf developed. Starting from day 21 DAA, plants did not present symptom evolution and maintained a grade 4, that is, they presented the yellowing described on day 14 DAA, with reasonable wrinkling and development delay, without the occurrence of necrosis.

At the $0.90 \mathrm{~g}$ a.i. ha ${ }^{-1}$ sub-dose of sulfometuron-methyl, on day 7 DAA, plants that received the application at the V4 stage and the ones receiving it at the V8 stage presented small visible alterations on some plants, such as slight yellowing and a small development delay. On day 14 DAA, phytotoxicity symptoms were more pronounced on plants that received the sub-dose at 
V4, since they presented chlorosis, wrinkling and a more pronounced development delay than plants sprayed at V8. On day 21 DAA, the EWRC grade was 5 for both stages, which presented remarkable development delay. In addition, when the application was at V4 there was the occurrence of tanning, wrinkling, leaf deformation and totally deformed apical bud and, at V8, there were plants with more rosettes, due to the shortening of the internodes. On day 28 and 42 DAA, the previously described symptoms at V4 contributed to an uneven stand, and at V8 symptoms evolved to the beginning of leaf necrosis.

At sulfometuron-methyl sub-doses of 1.35 and $1.80 \mathrm{~g}$ a.i. ha ${ }^{-1}$, plants that received them at the development stage V4 showed symptom evolution; at the highest sub-dose, on day 28 DAA, plants reached an EWRC grade equal to 8, that is, they presented extremely severe damages, which led to the death of most plants. It is worth highlighting that this grade was obtained in the evaluation of the plot as a whole, and that a few plants in the plot were able to recover, but without presenting productive potential, because of the deficient development. As for plants that received these sub doses at the development stage V8 there was symptom evolution, but until day 42 DAA the EWRC grade did not exceed number 6, characterized by a hard delay in plant development, wrinkling and necrosis of the leaves from the most pronounced apex. However, at least $80 \%$ of the leaves were not destroyed yet and, thus, until this evaluation it was not possible to consider these plants as dead, according to the EWRC grade scale.

In another study, Correia and Leite (2012) verified that coffee, citrus, cassava and rubber plants, when exposed to $15 \mathrm{~g}$ a.i. ha ${ }^{-1}$ of sulfometuron-methyl (100\% of the dose as ripener), did not show visual phytotoxicity symptoms. Thus, it is possible to state that maize culture is highly susceptible to this molecule, since with the $0.45 \mathrm{~g}$ a.i. ha ${ }^{-1}$ of sulfometuron-methyl maize plants presented phytotoxicity; it was more severe when the application occurred at the development stage V8.

\section{Morphological and production components}

As for the evaluated morphological and production components, there was interaction between applications at the development stages V4 and V8 and the sub doses of sulfometuron-methyl for plant height, ear insertion height, stalk diameter, ear length, kernel size, rows of kernels number, number of kernels per row, final stand and thousand kernel weight. Only for the number of photosynthetically active leaves and kernel productivity there was no significant interaction.

Staring from the $0.45 \mathrm{~g}$ a.i. ha ${ }^{-1}$ sub-dose of sulfometuron-methyl, it was noticed that, when the application occurred at the development stage V4, plants obtained greater height, ear insertion height and kernel size, compared to the application at the development stage V8. The stalk diameter was lower in plants that received the application at the development stage V4, starting from $0.90 \mathrm{~g}$ a.i. ha-1 of sulfometuron-methyl. The ear length was higher in plants that received the application at the development stage V4. It is worth highlighting that the application of 1.35 and $1.80 \mathrm{~g}$ a.i. ha ${ }^{-1}$ of sulfometuron-methyl sub doses at the development stage V8 of the maize culture resulted in plant death (Table 1).

The number of photosynthetically active leaves reduced with the increase of sulfometuronmethyl sub-doses, regardless of the phenological stage of maize (Figure 2). As for the stalk diameter, there was no difference for the sulfometuron-methyl application at V8, regardless of the sub dose. This was already expected, due to the fact that the application occurred when plants were at a more advanced development. On the contrary, for V4 applications, it was noticed that as the applied sub-dose increased, the stalk diameter reduced.

Similar results were observed in relation to the variables plant height, ear insertion height, ear length and kernel size, where it was possible to observe a reduction in these parameters according the applied dose increased. It is worth highlighting that applications at the development stage V8 were more damaging to plants, leading them to death at higher sub-doses.

It is recorded on Table 2 that the number of kernel rows, final stand and thousand kernel weight was higher for applications at V4 compared to V8 at sub doses of 1.35 and $1.80 \mathrm{~g}$ a.i. ha ${ }^{-1}$ of sulfometuron-methyl, once that plants that received these sub-doses at the development stage V8 died and did not produce kernels. The number of kernels per row on plants that received the 
Table 1 - Application split at the development stages V4 and V8 of maize culture within each sulfometuron-methyl sub-dose as for plant height, ear insertion height, stalk diameter, ear length and kernel size

\begin{tabular}{|c|c|c|c|c|c|}
\hline \multirow{2}{*}{ Application } & \multicolumn{5}{|c|}{ Sulfometuron methyl, g a.i. ha ${ }^{-1}$} \\
\hline & 0.00 & 0.45 & 0.90 & 1.35 & 1.80 \\
\hline & \multicolumn{5}{|c|}{ Plant height, $\mathrm{m}$} \\
\hline V4 & 2.37 & 2.11 & 1.76 & 1.60 & 1.57 \\
\hline V8 & 2.37 & 1.85 & 1.55 & 0.00 & 0.00 \\
\hline $\mathrm{Pr}>\mathrm{Fc}$ & 1.0000 & 0.0019 & 0.0093 & 0.0000 & 0.0000 \\
\hline \multirow[t]{2}{*}{$\mathrm{VC}(\%)$} & 6.99 & & & & \\
\hline & \multicolumn{5}{|c|}{ Ear insertion height, $\mathrm{m}$} \\
\hline V4 & 1.43 & 1.17 & 0.90 & 0.72 & 0.62 \\
\hline V8 & 1.43 & 0.93 & 0.76 & 0.00 & 0.00 \\
\hline $\operatorname{Pr}>\mathrm{Fc}$ & 1.0000 & 0.0006 & 0.0304 & 0.0000 & 0.0000 \\
\hline \multirow[t]{2}{*}{$\mathrm{VC}(\%)$} & 11.11 & & & & \\
\hline & \multicolumn{5}{|c|}{ Stalk diameter, $\mathrm{mm}$} \\
\hline V4 & 26.14 & 23.76 & 20.59 & 17.09 & 16.47 \\
\hline V8 & 26.14 & 25.32 & 27.28 & 26.57 & 26.73 \\
\hline $\mathrm{Pr}>\mathrm{Fc}$ & 1.0000 & 0.1819 & 0.0000 & 0.0000 & 0.0000 \\
\hline \multirow[t]{2}{*}{$\mathrm{VC}(\%)$} & 6.82 & & & & \\
\hline & \multicolumn{5}{|c|}{ Ear length, cm } \\
\hline V4 & 15.77 & 14.41 & 12.07 & 9.73 & 7.36 \\
\hline V8 & 15.77 & 12.58 & 10.62 & 0.00 & 0.00 \\
\hline $\mathrm{Pr}>\mathrm{Fc}$ & 1.0000 & 0.1943 & 0.3032 & 0.0000 & 0.0000 \\
\hline \multirow[t]{2}{*}{$\mathrm{VC}(\%)$} & 19.81 & & & & \\
\hline & \multicolumn{5}{|c|}{ Kernel size, $\mathrm{mm}$} \\
\hline V4 & 10.77 & 9.70 & 8.53 & 8.63 & 8.86 \\
\hline V8 & 10.77 & 8.52 & 7.23 & 0.00 & 0.00 \\
\hline $\mathrm{Pr}>\mathrm{Fc}$ & 1.0000 & 0.0176 & 0.0096 & 0.0000 & 0.0000 \\
\hline $\mathrm{VC}(\%)$ & 9.04 & & & & \\
\hline
\end{tabular}

$\operatorname{Pr}>\mathrm{Fc}$, probability $>$ calculated $\mathrm{F}$. VC variation coefficient.

sub-dose of $0.45 \mathrm{~g}$ a.i. ha $\mathrm{a}^{-1}$ of sulfometuron-methyl at V4 was also higher in relation to those receiving the application at $\mathrm{V} 8$.

It was verified that, for the number of rows of kernels, number of kernels per row, final stand and thousand kernel weight, as the applied sub-dose increased, there was a reduction in these evaluated components in both application periods, except for the thousand kernel weight, there was no difference for the application of sulfometuron-methyl at V4, regardless of the sub-dose (Figure 3).

Correia and Leite (2012) study the selectivity of the sulfometuron-methyl ripener on some cultures and concluded that at the dose of $7.5 \mathrm{~g} \mathrm{ha}^{-1}$ it was selective for peanuts and, at the two studied doses (7.5 and $\left.15 \mathrm{~g} \mathrm{ha}^{-1}\right)$, selective for coffee, citrus, cassava and rubber tree. Cotton, potato, bean, sunflower and grape cultures appeared susceptible to sulfometuron-methyl, due to the phytointoxication caused by this molecule. Silva et al. (2012) studied the phytotoxicity of sulfometuron-methyl on soybean culture and stated that small doses affected kernel productivity. Thus, it is evident that, depending on the species, the development stage and the ripener dose, plants that were submitted to sulfometuron-methyl drifting may respond differently, that is, they may present phytotoxicity or not.

At $0.45 \mathrm{~g}$ a.i. ha $\mathrm{a}^{-1}$ of sulfometuron-methyl sub-doses, the estimated productivity was $4,829.15 \mathrm{~kg} \mathrm{ha}^{-1}$, that is, approximately $3,250.00 \mathrm{~kg} \mathrm{ha}^{-1}$ less, when compared to the control sample treatment. Thus, with the results obtained from the kernel productivity of maize culture, it is possible to say that this culture is not tolerant to sulfometuron-methyl sub-doses; it is very 

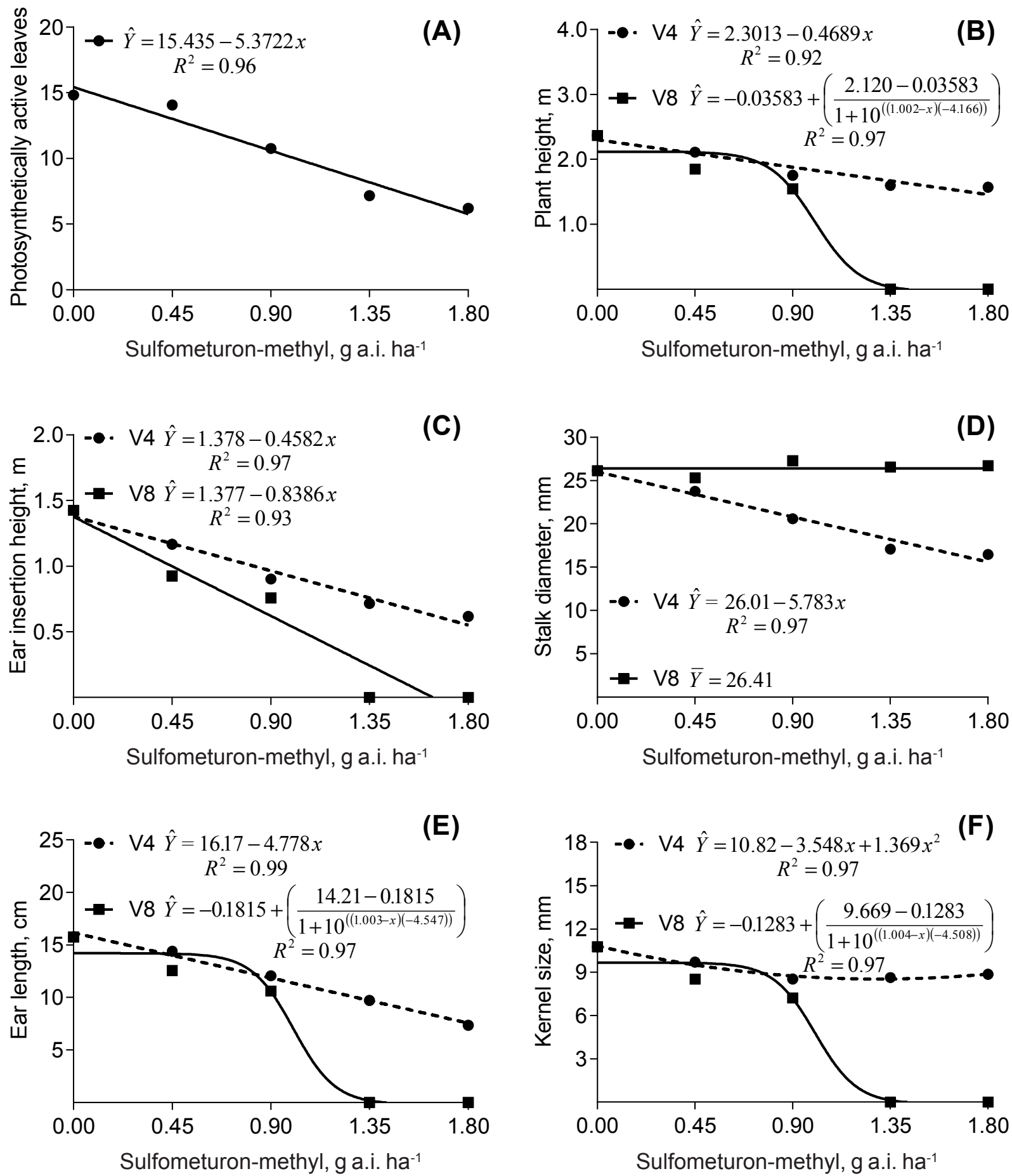

Figure 2 - Photosynthetically active leaves (A), plant height (B), ear insertion height (C), stalk diameter (D), ear length (E) and kernel size (F) according to the application of sulfometuron-methyl sub-doses at the development stages V4 and V8.

susceptible to sub-doses up to $1.8 \mathrm{~g}$ a.i. ha ${ }^{-1}$ of this sugarcane ripener (Figure 4). Novo and Miranda Filho (2006), when studying the effects of sulfometuron-methyl sub-doses on two potato cultivars as for tuber quality, reported that, as the sulfometuron-methyl sub-doses increased, more tubers emerged with protuberances and abnormalities, that is, the productive potential of this culture was negatively affected in response to the effect of this sulfonylurea.

The results showed that the maize hybrid SYN 7G17 is not selective to sulfometuron-methyl sub-doses as it is for sub-doses of ethephon and glyphosate (Felisberto et al., 2015, 2016). 
FELISBERTO, P.A.C. et al. Maize crop phytotoxicity in response to sub-doses of sulfometuron-methyl

Table 2 - Application split at the development stages V4 and V8 of maize culture within each sulfometuron-methyl sub-dose as for number of kernel rows, number of kernels per row, final stand and thousand kernel weight

\begin{tabular}{|c|c|c|c|c|c|}
\hline \multirow{2}{*}{ Application } & \multicolumn{5}{|c|}{ Sulfometuron-methyl, g a.i. ha $^{-1}$} \\
\hline & 0.00 & 0.45 & 0.90 & 1.35 & 1.80 \\
\hline & \multicolumn{5}{|c|}{ Number of kernel rows } \\
\hline V4 & 15.98 & 15.43 & 13.79 & 13.73 & 12.04 \\
\hline V8 & 15.98 & 15.68 & 14.72 & 0.00 & 0.00 \\
\hline $\mathrm{Pr}>\mathrm{Fc}$ & 1.0000 & 0.7319 & 0.2087 & 0.0000 & 0.0000 \\
\hline \multirow[t]{2}{*}{$\mathrm{VC}(\%)$} & 8.70 & & & & \\
\hline & \multicolumn{5}{|c|}{ Number of kernels per row } \\
\hline V4 & 31.05 & 29.78 & 24.40 & 22.48 & 19.23 \\
\hline V8 & 31.05 & 22.98 & 18.68 & 0.00 & 0.00 \\
\hline $\mathrm{Pr}>\mathrm{Fc}$ & 1.0000 & 0.0019 & 0.0073 & 0.0000 & 0.0000 \\
\hline \multirow[t]{2}{*}{$\mathrm{VC}(\%)$} & 13.96 & & & & \\
\hline & \multicolumn{5}{|c|}{ Final stand, plants $\mathrm{m}^{-2}$} \\
\hline V4 & 7.27 & 7.55 & 6.57 & 4.63 & 2.59 \\
\hline V8 & 7.27 & 7.59 & 7.36 & 0.00 & 0.00 \\
\hline $\mathrm{Pr}>\mathrm{Fc}$ & 1.0000 & 0.9140 & 0.0749 & 0.0000 & 0.0000 \\
\hline \multirow[t]{2}{*}{$\mathrm{VC}(\%)$} & 11.82 & & & & \\
\hline & \multicolumn{5}{|c|}{ Thousand kernel weight (g) } \\
\hline V4 & 285.50 & 258.74 & 240.75 & 247.09 & 297.51 \\
\hline V8 & 285.50 & 270.01 & 238.45 & 0.00 & 0.00 \\
\hline $\mathrm{Pr}>\mathrm{Fc}$ & 1.0000 & 0.6640 & 0.9291 & 0.0000 & 0.0000 \\
\hline $\mathrm{VC}(\%)$ & 17.08 & & & & \\
\hline
\end{tabular}

$\mathrm{Pr}>\mathrm{Fc}$, probability $>$ calculated $\mathrm{F}$. VC variation coefficient.
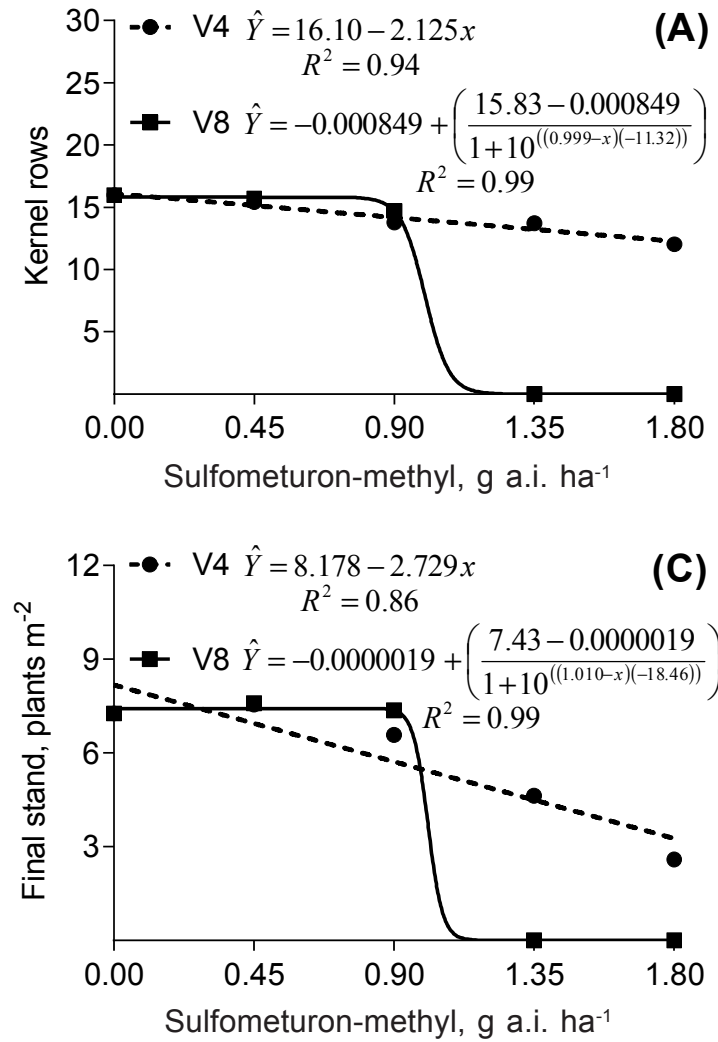
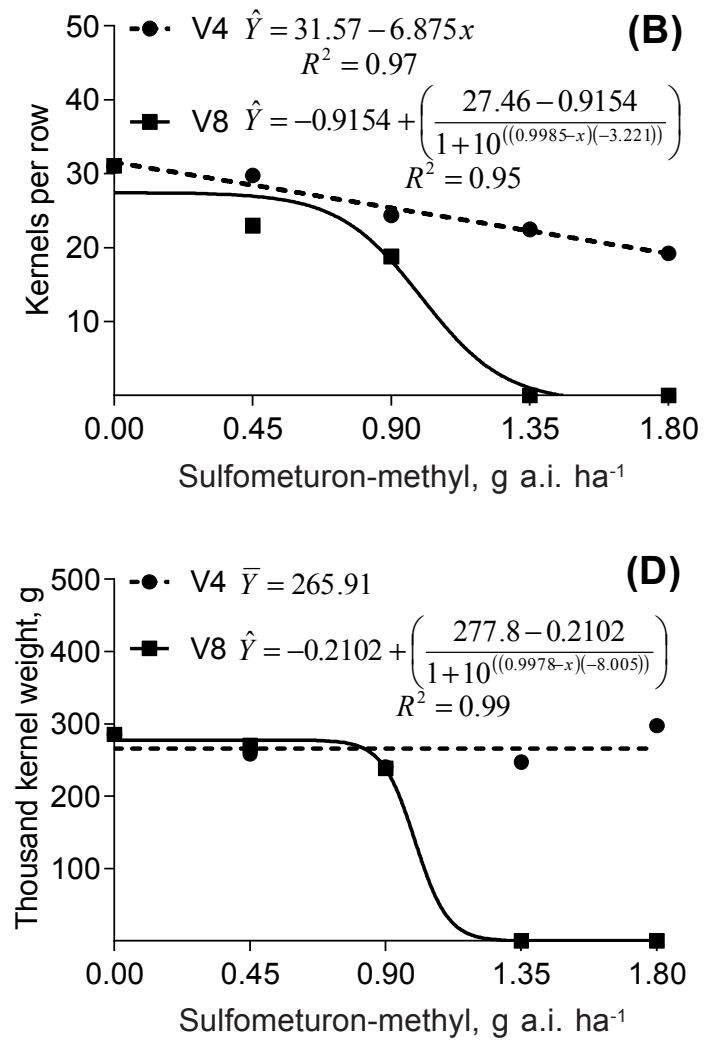

Figure 3 - Number of kernel rows (A), number of kernels per row (B), final stand (C) and thousand kernel weight (D) according to the application of sulfometuron-methyl sub-doses at the development stages V4 and V8. 


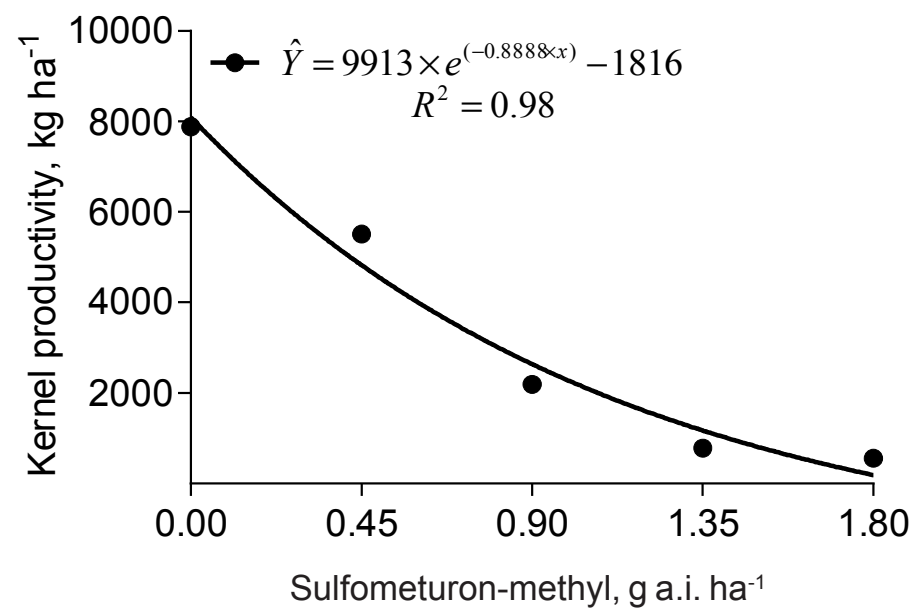

Figure 4 - Kernel productivity according to the application of sulfometuron-methyl sub-doses at the development stages V4 and V8.

Applications of sulfometuron-methyl at the development stage V8 of maize culture were more damaging to plants, leading them to death at most used sub-doses. It was verified that reduced doses of sulfometuron-methyl affected negatively the culture of maize. However, the occurrence of deposits of this product at higher doses or even at different development stages of the culture may reflect into more severe phytotoxic effects than the ones found in this study.

\section{REFERENCES}

Brasil. Ministério da Agricultura, Pecuária e Abastecimento. Regras para análise de sementes. Brasília: 2009. 399p.

Burney O.T., Jacobs D.F. Influence of sulfometuron methyl on conifer seedling root development. New Forest. 2009;37:85-97.

Caputo M.M. et al. Resposta de genótipos de cana-de-açúcar à aplicação de indutores de maturação. Bragantia. 2008;67:15-23.

Correia N.M., Leite G.J. Selectivity of the plant growth regulators trinexapac-ethyl and sulfometuron-methyl to cultivated species. Sci Agric. 2012;69:194-200.

Correia N.M., Villela G.B. Seletividade de trinexapac-ethyl and sulfometuron-methyl selectivity to young eucalyptus plants.

Planta Daninha. 2015;33:259-66.

Dalley C.D., Richard Jr E.P. Herbicides as ripeners for sugarcane. Weed Sci. 2010;58:329-33.

European Weed Research Council - EWRC. Methods in weeds research. Weed Res. 1964;4:88.

Felisberto P.A.C. et al. Sub-doses of 2-chloroethylphosphonic acid in vegetative stages of corn cultivation. Rev Bras Herbic. 2015;14:164-70.

Felisberto P.A.C. et al. Subdoses de glyphosate não reduzem a produtividade da cultura do milho. Rev Bras Herbic. 2016;15:290-6.

Köppen W. Climatologia con un studio de los climas de la Tierra. Buenos Aires: 1931. 320p.

Leite G.H.P., Crusciol C.A.C. Reguladores vegetais no desenvolvimento e produtividade da cana-de-açúcar. Pesq Agropec Bras. 2008;43:995-1001.

Meschede D.K. et al. Efeitos do glyphosate e sulfometuron-methyl no crescimento e na qualidade tecnológica da cana-de-açúcar. Planta Daninha. 2010;28:1135-41.

Meschede D.K. et al. Alteração fisiológica da cana-de-açúcar pela aplicação de glyphosate e sulfometuron-methyl. Planta Daninha. 2011;29:413-9. 
Miranda Filho H.S., Novo M.C.S.S. Fitotoxicidade de sulfonilureias em duas cultivares de batata. Rev Bras Herbic. 2006;5:10-18.

Novo M.C.S.S., Miranda Filho H.S. Tuberização de dois cultivares de batata sob aplicação de sulfonilureias. Planta Daninha. 2006:24:115-21.

Oliveira Júnior R.S. Mecanismo de ação de herbicidas. In: Oliveira Júnior R.S., Constantin J., Inoue M.H. Biologia e manejo de plantas daninhas. Curitiba: Omnipax, 2011. p.141-92.

Osiecka A., Minogue P.J. Sequential sulfometuron methyl applications in Eucalyptus benthamii plantations. Weed Technol. 2015;29:243-54.

Pfleeger T. et al. Comparing effects of low doses levels of herbicides on greenhouse na field-grwn potatoes (Solanum tuberosum L.), soybeans (Glycine max L.), and peas (Pisum sativum L.). Environ Toxicol Chem. 2011;30:455-68.

Roman E.S. et al. Como funcionam os herbicidas: da biologia à aplicação. Passo Fundo: Berthier, 2007. 158p.

Silva R.P. et al. Intoxicação de plantas de soja com Curavial ${ }^{\circledR}$. In: Anais do $28^{\circ}$ Congresso Brasileiro de Plantas Daninhas. Viçosa, MG: SBCPD, 2012. p.101-5.

Warwick S.I. et al. Acetolactate synthase (ALS) target-site mutations in ALS inhibitor-resistant russian thistle (Salsola tragus). Weed Sci. 2010:58:244-51.

Zhou Q. et al. Action mechanisms of acetolactate synthase-inhibiting herbicides. Pestic Biochem Physiol. 2007;89:89-96. 